\title{
MSME Socio-Economic Analysis in the Context of Development of the Muaro Jambi Temple Area
}

\author{
Zulfanetti Zulfanetti ${ }^{1}{ }^{*}$, Heriberta Heriberta $^{2,}$ Etik Umiyati ${ }^{3}$ \\ ${ }^{1,2,3}$ Lecturer in Faculty of Economics and Business, Jambi University, Indonesia \\ *Corresponding author's email:zulfa_netti@unja.ac.id
}

\begin{abstract}
The aims of this study are to analyze: 1). the socio-economic conditions; 2). the factors that influence MSMEs in the development of the Muaro Jambi Temple area. This study used primary data with descriptive and quantitative methods with multiple regression analysis tools. The results showed that the type of business of MSMEs in the Muaro Jambi Temple area was known to be 21 respondents with the type of culinary business or selling food and beverages, the average length of business was 7 years, the average working hours were 269 hours. Simultaneously the variables of operating capital, labor, length of business, hours of work, education, age and gender affect the income of MSME players in the context of developing the Muaro Jambi area. Partially operating capital, working hours and education variables have a positive and significant effect on MSMEs income in the context of developing the Muaro Jambi Temple area.
\end{abstract}

Keywords: Socio-Economic, MSMEs ,Income, Area Development, Muaro Jambi Temple.

\section{INTRODUCTION}

Tourism plays an important role in global and national economic and community development, especially in increasing income and creating jobs. Globally, the tourism industry in 2018 generated $10.4 \%$ of the Gross Domestic Product (GDP) and absorbed $10.0 \%$ of the workforce worldwide [1] [2]. According to (UNWTO [3] the number of international tourist visits has increased from year to year. In 2018 the number of international tourist arrivals worldwide reached 1.4 billion. The year also marked the seventh consecutive year that tourism export growth $(+$ $4 \%$ ) outstripped merchandise export growth (+3\%). Based on this rapid growth rate, it is predicted that international arrivals will reach 1.8 billion by 2030 .

Nationally, the tourism sector plays an increasingly important role, as reflected in its development and contribution through regional income, foreign exchange earnings, regional development, absorption of investment and employment as well as business development in various parts of Indonesia. Nationally, the contribution of the tourism sector to GDP amounted to Rp. 946, 09 trillion or reached $9 \%$ in 2014 . The tourism industry's contribution to foreign exchange amounted to Rp. 120 trillion and as much as 11 million people to the absorption of labor in 2014. The tourism sector has encouraged and attracted the development of other sectors such as hotels and restaurants, the handicraft industry, transportation and other related service sectors. The tourism sector also creates a multiplier effect on accelerating economic growth and providing wider employment opportunities if tourism is developed through sustainable promotion. The government plans a tourism development program that is carried out with various strategies such as developing tourist markets, developing tourism images, developing tourism marketing partnerships, and developing tourism promotions. All of these strategies are carried out in order to achieve the tourism growth target. The target of tourism development is the increase in local businesses in the tourism business and the increasing number of certified local workers [4].

Jambi province has a famous area of tourist destinations; the temple complex Muaro located in the village of Muara Jambi, District Muaro Sebo, Muaro Jambi, the Archeological Site is a temple complex HinduBuddhist broadest in Indonesia are likely relics of the kingdom of Srivijaya and the Malay Kingdom. This temple has an area of about 12 square $\mathrm{km}$ with a length of more than $7 \mathrm{~km}$ and its area reaches 260 hectares. The Muaro Jambi Temple Complex contains a total of 61 temple buildings, most of which are still in the form of mounds of earth (menapo) that have not been excavated (occupied). 
As one of the largest cultural tourism destinations in Jambi Province, especially Muaro Jambi Regency, the increase in visitors is not so significant from year to year, both from local and foreign tourists, the management of this area has not been optimal as a tourist area both in spatial and non-spatial terms. The spatial side includes infrastructure, transportation, accommodation and supporting facilities for tourist areas, while the non-spatial side includes the provision of lodging facilities, souvenir shops, restaurants, regional arts, promotional media and other aspects related to tourism development. While this area has great potential to be developed with the aim of increasing regional income and the income of rural communities around the area. This condition is obviously the responsibility of stakeholders, local government and community leaders associated with the development of the Muaro Jambi Temple tourism area.

The economy of the local community will develop with the development of tourist destinations, people can open household businesses, culinary delights, manufacture souvenirs, rent bicycles, open parking services, homestays, tour guides and others. Community household businesses (MSEs) are an important component to be developed, because one of the sustainable tourism developments is to empower and improve the welfare of local communities. Observation of individual characteristics, business potential, and improvement of the quality of the resulting product is very necessary.

According to Timothy in Sulistyadi et al [5] community-based tourism is related to the benefits obtained and assistance planning efforts that protect local communities and other interested groups, who supervise social processes to create prosperity. Meanwhile, according to Murphy [6], it emphasizes a strategy that is focused on identifying the goals of local communities and their desire and ability to absorb the benefits of tourism. Each community should be encouraged to identify their own goals and direct tourism to increase the needs of local communities. Community-based tourism creates a more sustainable tourism industry that focuses on local communities in tourism planning, maintenance and development [7]. If the tourism strategy is to be sustainable then community development and empowerment must be developed as the main objective of the partnership. Not only in relation to the public, or through public participation, but as a form of local community development [8]. There are many potential benefits when people living or working in a tourist destination are involved in tourism planning as it increases the legitimacy of members of the political community. This means that community members have a greater influence on decisions that affect their lives [9].

The local community as the party that receives tourists, needs to be involved in the process of developing tourism, so that success is guaranteed. The failure of regional tourism development that does not involve the general public is due to lack of planning and does not understand environmental conditions, both economic, political and social. By not involving the local community, it will hamper the development of tourism. In this way, community involvement plays a very important role in tourism development. The role of local communities can create a conducive situation for tourists so as to provide a sense of comfort for tourists.

The various roles of local communities according to Wardiyanto [10] in the development of tourism in their area are to become tour guides. As hosts, local people, as those who know and understand their area well and deeply, can become tour guides who come; Become a tourism business actor to fulfill the basic needs of tourists who come for a vacation. Local people can establish tourism service businesses such as accommodation, transportation, food services, etc. This can support the progress of tourism and can increase the income of the surrounding community; Actualizing past cultures Daily activities and cultural arts activities, both ongoing and past cultures that were carried out by their ancestors and now no longer exist in the community. It can be an attraction area and developing Community Tourism Institutions can play a role in developing an institution aimed at supporting tourism in their area. The implementation can be done alone or in collaboration with the government or related parties. The development of this institution is intended for the formation of tourism awareness groups and tourism villages. In developing a tourist village, the community can offer the potential of their own design and what is around it to be offered to tourists who come. Many things can be developed by the community so that it can become a tourist attraction.

The problems that will be analyzed in this study are (1) analyzing the socio-economic conditions and (2) analyzing the factors that influence MSMEs in the development of the Muaro Jambi Temple area.

\section{METHOD}

The type of data used in this study is primary data obtained directly from the object of research and collected using a questionnaire. In answering the problem of the research used an analysis on the descriptive quantitative data, using multiple linear regression analysis as follows: $\mathrm{Y}=\beta_{0}+\beta_{1} \mathrm{X}_{1}+\beta_{2} \mathrm{X}_{2}+\beta_{3} \mathrm{X}_{3}+\beta_{4} \mathrm{X}_{4}+\beta_{5} \mathrm{X}_{5}+$ $\beta_{6} \mathrm{X}_{6}+\beta_{7} \mathrm{X}_{7}+\mathrm{e}_{\mathrm{i}}$

Note:

$\mathrm{Y}=$ Income of MSME Players (Rupiah)

$\beta_{0}=$ Constant.

$\beta_{1}, \beta 2, \ldots, \beta_{7}=$ Regression Coefficient

$\mathrm{X}_{1}=$ Operating Capital (Rupiah)

$\mathrm{X}_{2}=$ Labor (Person)

$\mathrm{X}_{3}=$ Length of Business (Years)

$\mathrm{X}_{4}=$ Hours of Work (Hours) 
$\mathrm{X}_{5}=$ Education (Years)

$\mathrm{X}_{6}=$ Age (Years)

$\mathrm{X}_{7}=$ Gender

$\mathrm{e}_{\mathrm{i}}=$ Standard Error

\section{RESULTS AND DISCUSSION}

3.1. The Socio-Economic Conditions of MSMES

Table 1. Demographic Analysis of Respondents

\begin{tabular}{|c|c|c|}
\hline Description & Respondent Profile & \\
\hline Age & Number & Percentage \\
\hline $20-24$ & 8 & $16.0 \%$ \\
\hline $25-29$ & 6 & $12.0 \%$ \\
\hline $30-34$ & 9 & $18.0 \%$ \\
\hline $35-39$ & 8 & $16.0 \%$ \\
\hline $40-44$ & 6 & $12.0 \%$ \\
\hline $45-49$ & 4 & $8.0 \%$ \\
\hline $50-54$ & 5 & $10.0 \%$ \\
\hline $55-59$ & 3 & $6.0 \%$ \\
\hline \multirow[t]{2}{*}{$\geq 60$} & 1 & $2.0 \%$ \\
\hline & Education & \\
\hline No school & 3 & $6.0 \%$ \\
\hline SD & 12 & $24.0 \%$ \\
\hline Junior High School & 11 & $22.0 \%$ \\
\hline High school & 17 & $34.0 \%$ \\
\hline D3 & 2 & $4.0 \%$ \\
\hline \multirow[t]{2}{*}{$\mathrm{S} 1$} & 5 & $10.0 \%$ \\
\hline & Gender & \\
\hline Male & 24 & $48.0 \%$ \\
\hline \multirow[t]{2}{*}{ Women } & 26 & $52.0 \%$ \\
\hline & Marital status & \\
\hline Single & 10 & $20.0 \%$ \\
\hline Married & 40 & $80.0 \%$ \\
\hline
\end{tabular}

Source: Research Results in 2020 (Data processed)

Based on table 1, the average age of MSME

industry players is 37 years, $34.0 \%$ high school education , $52.0 \%$ women and $48.0 \%$ men , and as much as $80.0 \%$ are married.

Table 2. Business Analysis of Respondents

\begin{tabular}{ccc}
\hline Description & Respondent Profile & \\
\hline Type of business & Number & Percentage \\
\hline Motorized transportation service & 5 & $10.0 \%$ \\
providers & 21 & $42.0 \%$ \\
Culinary / selling food and drinks & 1 & $2.0 \%$ \\
Photography services & 9 & $18.0 \%$ \\
Bike rental & 4 & $8.0 \%$ \\
Selling souvenirs & 5 & $10.0 \%$ \\
Tour guide & 4 & $8.0 \%$ \\
Homestay / lodging & 1 & $2.0 \%$ \\
Rental mat & &
\end{tabular}

Length of Business 
$1990-1995$
$1996-2001$
$2002-2007$
$2008-2013$
$2014-2019$

$150-200$

201-251

252-302

303-353

$354-404$

$405-455$

$\geq 456$

One's own

Family owned

One's own

Bank

Family loan

Bank

Family loan
1

1

4

18

\section{Working hours}

10

$20.0 \%$

11

$22.0 \%$

20

2

5

1

1

Business Ownership

49

1

Source of Initial Capital

44

$88.0 \%$

4

2

Sources of Operational Capital

47

$94.0 \%$

$4.0 \%$

$2.0 \%$

$2.0 \%$

$2.0 \%$

$8.0 \%$

$36.0 \%$

$40.0 \%$

$4.0 \%$

$10.0 \%$

$2.0 \%$

$2.0 \%$

$98.0 \%$

$2.0 \%$

$8.0 \%$

$4.0 \%$

$\begin{array}{ll}2 & 2.0 \%\end{array}$

Source: Research Results in 2019 (Data processed)

Based on table 2, the types of businesses of MSMEs in the Muaro Jambi Temple area, it is known that $42.0 \%$ with the type of culinary business / selling food and beverages, the average length of business is 7 years, the average working hours are 269 hours, as much as $98.0 \%$. As many as $88.0 \%$ of

Table 3. Estimation Results of Factors Affecting MSMEs

\begin{tabular}{crrrr}
\hline \hline Variable & & & & \\
& Coefficient & Std. Error & t-Statistic & Prob. \\
\hline \hline C & & & \\
X1 & -4114981. & 1030246. & -3.994174 & 0.0003 \\
X2 & 0.079067 & 0.011968 & 6.606336 & 0.0000 \\
X3 & -187801.0 & 112088.9 & -1.675466 & 0.1013 \\
X4 & -36841.35 & 29320.77 & -1.256493 & 0.2159 \\
X5 & 19228.43 & 1985,415 & 9.684843 & 0.0000 \\
X6 & 84092.35 & 47693.67 & 1.763177 & 0.0851 \\
X7 & 7266,600 & 17604.01 & 0.412781 & 0.6819 \\
X6 & 368026.7 & 290458.9 & 1.267053 & 0.2121
\end{tabular}




\begin{tabular}{lrlr}
\hline \hline & & & \\
R-squared & 0.876109 & Mean dependent var & 2062300. \\
Adjusted R-squared & 0.855461 & SD dependent var & 2398205. \\
SE of regression & 911757.5 & Akaike info criterion & 30.42978 \\
Sum squared reside & $3.49 \mathrm{E}+13$ & Schwarz criterion & 30,73571 \\
Log likelihood & $-752,7446$ & Hannan-Quinn criter. & 30,54628 \\
F-statistic & 42.42971 & Durbin-Watson stat & 1.600057 \\
Prob (F-statistic) & 0.000000 & &
\end{tabular}

From table 3, the operational capital variable regression coefficient can be seen that the $t$ value is 6.606336 with the probability of working capital variables of 0.0000 or less than the value $\alpha=0.10$ $(0.0000<0.10)$, then $\mathrm{H}_{0}$ is rejected and $\mathrm{H}_{\mathrm{a}}$ is accepted. From these results, it can be concluded that the operating capital variable individually has a significant influence on the income of MSMEs.

The regression coefficient of the labor variable can be seen that the $t$ value is -1.675466 with the probability of the labor variable being 0.1013 or greater than the value of $\alpha=0.10(0.1013>0.10)$, then $\mathrm{H}_{0}$ is accepted and $\mathrm{H}_{\mathrm{a}}$ is rejected. From these results, it can be concluded that the individual labor variable has no significant effect on the income of MSMEs.

The regression coefficient for the length of business of the business can be seen that the value of $t$ count is -1.256493 with the probability of the variable length of business of 0.2159 or greater than the value of $\alpha=0.10(0.2159>0.10)$, then $\mathrm{H}_{0}$ is accepted and $\mathrm{H}_{\mathrm{a}}$ is rejected. From these results, it can be concluded that the variable length of business individually has no significant effect on the income of MSMEs.

The regression coefficient of working hours variable can be seen that the $t$ value is 9.684843 with a variable probability of working hours of 0.0000 or less than the value of $\alpha=0.10(0.0000<0.10)$, then $\mathrm{H}_{0}$ is rejected and $\mathrm{H}_{\mathrm{a}}$ is accepted. From these results, it can be concluded that the individual working hours variable

The regression coefficient of the education variable can be seen that the $t$ value is 1.763177 with the probability of the education variable being 0.0851 or less than the value of $\alpha=0.10$ $(0.0851>0.10)$, then $\mathrm{H}_{0}$ is rejected and $\mathrm{H}_{\mathrm{a}}$ is accepted. From these results, it can be concluded that the individual education variables have a significant effect on MSME income.

The regression coefficient for the age variable can be seen that the $t$ value is 0.412781 with the probability of the age variable being 0.6819 or greater than the value of $\alpha=0.10(0.6819>0.10)$, then $\mathrm{H}_{0}$ is accepted and $\mathrm{H}_{\mathrm{a}}$ is rejected. From these results, it can be concluded that the age variable individually has no significant effect on the income of MSMEs.

The regression coefficient for the gender variable can be seen that the $\mathrm{t}$ value is 1.267053 with the probability of the gender variable of 0.2121 or greater than the value of $\alpha=0.10(0.2121>0.10)$, then $\mathrm{H}_{0}$ is accepted and $\mathrm{H}_{\mathrm{a}}$ is rejected. From these results, it can be concluded that the gender variable individually has an insignificant effect on the income of MSMEs.

The influence of the independent variable (operating capital, labor, old business, hours of work, education, age and sex) on the dependent variable (revenue SMEs) are indicated by a large coefficient of determination $\mathrm{R}^{2}$. R-squared figures obtained by 0.876109 or $87,61 \%$ so it can be stated to have a strong correlation to the closeness of revenue SMEs. This explains that the influence of variables of operating capital, labor, length of work, working hours, education, age and gender on MSME income is $87.61 \%$ while the remaining $12.39 \%$ is influenced by other variables not included in this research model.

\section{CONCLUSION}

The profile of MSME players is that the average age of MSME industry players is 37 years, $34.0 \%$ high school education, $52.0 \%$ women and $48.0 \%$ men, and as much as $80.0 \%$ married. MSMEs in the Muaro Jambi Temple area, it is known that as many as $42.0 \%$ with the type of culinary business / selling food and beverages, the average length of business is 7 years, the average working hours are 269 hours, as many as $98.0 \%$ are self-owned businesses, as many as 88 , $0 \%$ used their own capital as initial capital and $94.0 \%$ used their own capital as operating capital.

The factors that influence the income of MSME players in the Muaro Jambi Temple area are jointly influenced by the variables of working capital, labor, length of business, working hours, education, age and gender. While partially the operating capital, working hours and education variables have a significant effect on the income of MSME players in the Muaro Jambi 
Temple area. Meanwhile, the variables of labor, length of business, age and type of business did not have a significant effect on MSME actors in the Muaro Jambi Temple area.

\section{ACKNOWLEDGMENT}

The researchers would like to thank all those who have helped carry out this research, especially to the Rector of the University, the Dean of the Faculty of Economics and Business and the Chairperson of LPPM Jambi University for their trust in researchers to carry out this research and researchers. funding support. Letter of Agreement on Business and Economic Group Research Scheme Faculty of Economics, Jambi University, 2020 Fiscal Year Number: 321 / UN21.18 / PG / SPK / 2020 dated April 20, $2020 \mathrm{We}$ appreciate Micro, Small and Medium Businesses in the tourist area of Muaro Jambi Temple who respondents.

\section{REFERENCES}

[1] WEF. 2019. The Travel and Tourism Competitiveness Report. Geneva.
[2] WTTC. 2019. The Economic Impact of Travel and Tourism. March 2019. London.

[3] UNWTO. 2017. Annual Report.

[4] LPEM, 2018. Final Report. Study of the Impact of Tourism Around the Indonesian Economy. LPEM. FEB-UI, Jakarta.

[5] Y. Sulistyadi, F. Eddyono, B. Hasibuan. 2017. Model of Sustainable Tourism Development Strategy of the Thousand Island-Jakarta Tourism Area. J. Econ. Manag. Trade, 19, 1-17.

[6] P.E. Murphy. 2013. Tourism: a community approach. London: Methuen.

[7] B. Sue. 2006. Community development through tourism. Collingwood: Land links Press.

[8] G. Hughes. 1995. Authenticity in tourism annals of tourism research. 22: $181 Đ 803$.

[9] G. Benveniste. 1989. Mastering the politics of planning: Crafting credible plans and policies that make a difference. San Francisco: JosseyBass.

[10] Wardiyanto and Baiquni. 2011. Tourism Planning and Development, LubukAgung, Bandung. 